\title{
Scaling Up Sap Flow Measurements from the Stem Scale to the Individual Scale for Multibranched Caragana Korshinskii on the Chinese Loess Plateau
}

\author{
Guohui Wang $1,2,3$, Yuying Shen $1,2,3, * \mathbb{C}$, Xianlong Yang ${ }^{1,2,3}$, Zhixue Chen ${ }^{1,2,3}$ and Baoru Mo ${ }^{4}$ \\ 1 State Key Laboratory of Grassland Agro-Ecosystems, Lanzhou University, Lanzhou 730020, China \\ 2 Key Laboratory of Grassland Livestock Industry Innovation, Ministry of Agriculture and Rural Affairs, \\ Lanzhou University, Lanzhou 730020, China \\ 3 Engineering Research Center of Grassland Industry, Ministry of Education, College of Pastoral Agriculture \\ Science and Technology, Lanzhou University, Lanzhou 730020, China \\ 4 Institute of Ecological Management of the Loess Region, Gansu Academy of Forestry Sciences, \\ Lanzhou 730000, China \\ * Correspondence: yy.shen@lzu.edu.cn; Tel.: +86-891-5263-0931
}

Received: 13 July 2019; Accepted: 4 September 2019; Published: 9 September 2019

\begin{abstract}
The traditional heat balance method for measuring plant sap flow (SF) becomes troublesome and uneconomic for multibranched shrub species if all their stems are used for the measurement. The objectives of this study were to explore specific relationships between stem-scale SF and plant morphological traits and then to scale up SF measurements from the stem scale to the individual scale for Caragana korshinskii Kom., a dominant shrub species on the Chinese Loess Plateau. Sap flow was measured for twenty-one stems from three representative individuals from July to September 2018 during the rainy season. The results indicated that the stem-scale SF in C. korshinskii presented a positive linear correlation with the stem base diameter (SBD), stem length (SL), primary branch numbers in the stem (PBN), and estimated stem biomass (W). The SBD-based statistical models performed well in estimating the stem-scale SF, with an $R^{2}$ value of 0.9726 and root mean squared error (RMSE) of $2.5389 \mathrm{~g} \mathrm{~h}^{-1}$. Over the canopy projection area, the individual-scale transpiration flows for the three selected C. korshinskii were 1.91, 1.10, and $1.59 \mathrm{~mm} \cdot \mathrm{d}^{-1}$. In addition, stem-scale SF was positively and linearly correlated with air temperature, photosynthetically active radiation, vapor pressure deficit, reference crop evapotranspiration, and variable transpiration. This study sheds light on morphological and meteorological influences on stem-scale SF and has made contributes to the accurate and rapid estimation of the plant sap flow from easily available morphological traits for multibranched shrub species in semiarid regions. Limitations, however, may exist for the established model when it is used to estimate SF of $C$. korshinskii during the water-limited dry season. Our study deserves further exploration of a more general model to have a better estimation of SF for C. korshinskii in both dry and rainy seasons.
\end{abstract}

Keywords: sap flow; morphological traits; meteorological factor; stem scale; individual scale

\section{Introduction}

Soil water is a key factor that limits vegetation growth in arid and semiarid areas. An understanding of plant water use patterns of vegetation could contribute to the effective management of limited water resources [1]. Sap flow (SF) is the water flux across a given section of stem diameter at a given period and is an important component of the water balance in forest ecosystems [2-4]. Sap flow can reflect water transportation and water utilization characteristics in plants. The heat balance technique was used to determine sap flow rate $\left(\mathrm{g} \cdot \mathrm{h}^{-1}\right)$ and sap flux density $\left(\mathrm{m}^{3} \cdot \mathrm{m}^{-2} \cdot \mathrm{h}^{-1}\right)$ [5]. The majority of 
methods measuring sap flux density utilize the heat pulse (HP) method, which only measures heat velocity $\left(\mathrm{m} \cdot \mathrm{s}^{-1}\right)$. The heat pulse method is limited to plants with stem diameters large enough to accommodate the physical insertion of probes, and it also normally causes sap velocities to vary with radial depth due to differences in tissue structure and xylem function in woody species [6]. However, there are also continuous heat sap flux density methods, including the heat pulse and thermal diffusion methods $[5,7,8]$.

Currently, these methods are rarely used to determine shrub SF because the studied plants are always branched and have no obvious trunks $[9,10]$. A probe would need to be inserted into the base of the plants close to the main root, and thus, the shrub growth would be affected [10]. This method can accurately measure SF for each branch without damaging the growth of shrubs [11]. However, due to high equipment costs, only part of the stem is used to measure SF, thus making it difficult to estimate SF for the entire plant. To our knowledge, many scholars have used the heat balance method to study the SF characteristics of shrubs at the stem scale $[8,12-16]$, but studies on how to scale up SF from the stem scale to the individual scale are still underrepresented in the literature [12,17-19]. For example, Chabot et al. [17] used stem leaf area and sugarcane leaf area to estimate the SF of individual sugarcane plants. Similar statistical estimation models were also established by Huang and Zhang [12] for Caragana korshinskii Kom. and Artemisia ordosica Krasch and by Zha et al. [19] for Artemisia ordosica. In addition, Yue et al. [18] estimated the mean daily stand transpiration of C. korshinskii using established models for stem leaf area, the plot-scale total leaf area, land surface area, and SF. These studies, however, only used the stem leaf area and individual leaf area to estimate SF and did not consider other morphological traits, such as stem length, diameter, and biomass.

The Chinese Loess Plateau is a region that has experienced severe soil erosion, vegetation degradation, and soil desertification [20,21]. The national Grain for Green project was initiated in 1999 to control soil erosion and systemic degradation [22,23]. Most of the traditional farmlands on steep slopes were converted to pasture grasslands, shrublands, and forestlands during this process [24,25]. The runoff reduction was notable, reaching more than $50 \%$ after forestation in the semihumid and semiarid regions of China [26]. Caragana korshinskii was one of the main introduced shrub species, and understanding its transpiration characteristics is necessary to support its population development on the water-limited Loess Plateau. In this study, a field experiment was conducted in the Dingjia Mountains watershed in a typical semiarid region of the Loess Plateau. The SF of C. korshinskii was measured using the stem heat balance method (SHB), and relevant environmental and morphological factors were monitored simultaneously. The main objectives of this study were: (1) to explore the specific relationships between stem-scale SF and plant morphological traits and meteorological factors; and (2) to scale up the SF of C. korshinskii from the stem scale to the individual scale.

\section{Materials and Methods}

\subsection{Study Area}

The experiment was conducted in the Dingjia Mountains watershed $\left(35^{\circ} 43^{\prime} 30^{\prime \prime}-35^{\circ} 44^{\prime} 10^{\prime \prime} \mathrm{N}\right.$, $104^{\circ} 33^{\prime} 40^{\prime \prime}-104^{\circ} 34^{\prime} 10^{\prime \prime}$ E) of Dingxi city, a typical shallow gully on the Loess Plateau (Figure 1). This area consists of perennial artificial bush and has a semiarid climate; the mean annual precipitation is $386 \mathrm{~mm}$, and most of the rain falls during July and September. The annual potential evaporation is approximately $1439 \mathrm{~mm}$. The mean annual temperature is $6.8^{\circ} \mathrm{C}$, with the lowest mean value of $-7.9^{\circ} \mathrm{C}$ in January and the highest mean value of $38.5^{\circ} \mathrm{C}$ in July. The soil thickness varies from 40 to $60 \mathrm{~m}$ [25]. The soil type is mainly loess soil that has low fertility and is vulnerable to erosion. The predominant land use types in the catchment are rain-fed farmland, sparse native grassland, pasture grassland, shrubland, forestland, and fallow cropland. The natural vegetation in the study area consists of sparse grass with shallow roots, such as Stipa bungeana Trin., Leymus secalinus (Georgi) Tzvel., and Heteropappus altaicus (Willd.) Novopokr. var. The introduced vegetation types include 
Caragana korshinskii Kom., Pinus tabulaeformis Carr. var., Platycladus orientalis (L.) Franco, and Amygdalus davidiana (Carrière) de Vos ex Henry var.
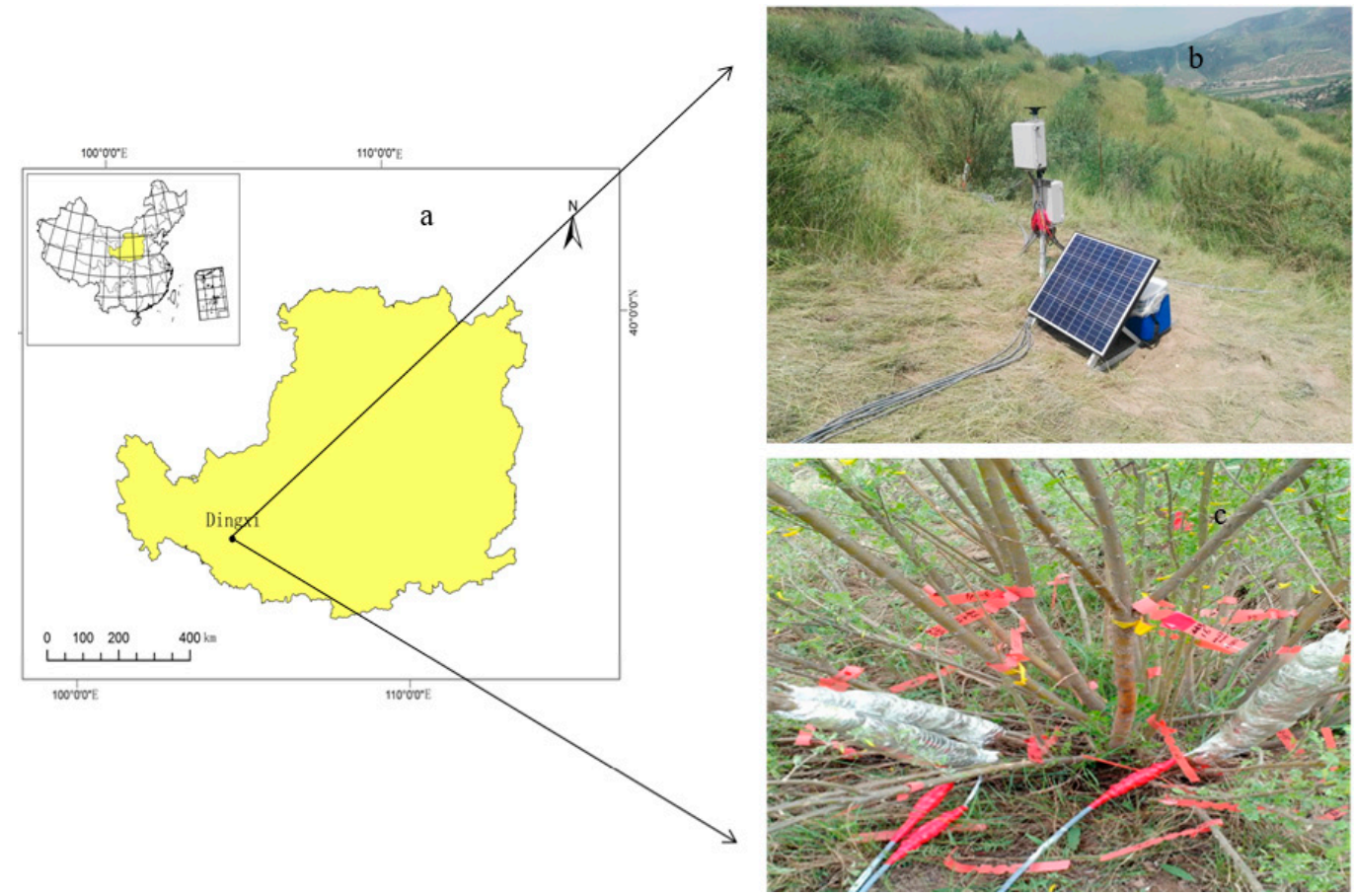

Figure 1. Location of the study area (a) and photos of the devices used to measure sap flow in the stems $(\mathbf{b}, \mathbf{c})$.

The dynamics of the meteorological variables in the study site are shown in Figure 2. Altogether, 29 rain events occurred during the study period, and the total precipitation $(\mathrm{P})$ was $177.8 \mathrm{~mm}$. The average rainfall was $2.82 \mathrm{~mm} \cdot \mathrm{d}^{-1}$, with the maximum rainfall $(46.0 \mathrm{~mm})$ occurring on August 21 and the minimum rainfall $(0.2 \mathrm{~mm})$ occurring on September 16 and 17. The air temperature (T) averaged $17.9^{\circ} \mathrm{C}$, ranging from 6.7 to $23.5^{\circ} \mathrm{C}$. The photosynthetically active radiation (PAR) readings averaged $156.82 \mu \mathrm{mol} \cdot \mathrm{m}^{-2} \cdot \mathrm{s}^{-1}$, ranging from 27.3 to $264.3 \mu \mathrm{mol} \cdot \mathrm{m}^{-2} \cdot \mathrm{s}^{-1}$. Both T and PAR tended to decrease from July to September during the study period.

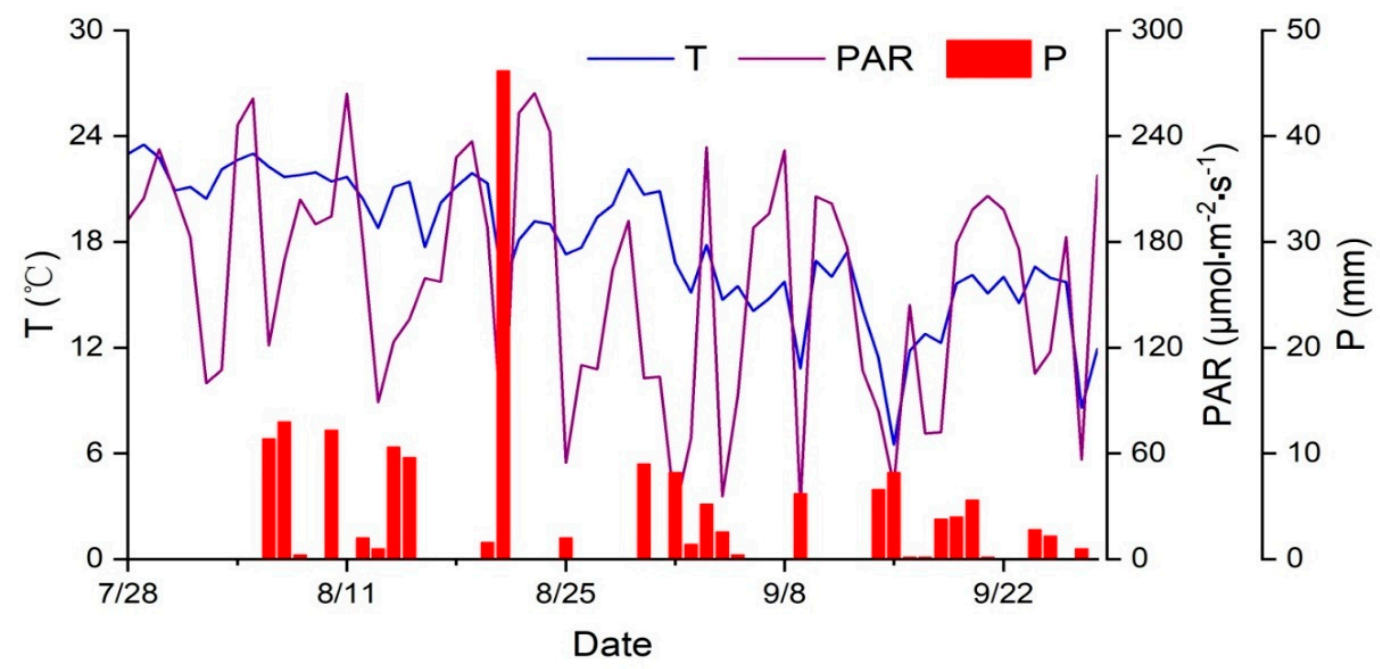

Figure 2. Daily air temperature (T), photosynthetically active radiation (PAR), and precipitation (P) during the study period. 


\subsection{Measurement of Sap Flow}

Three robust 33-year-old C. korshinskii spaced 7.0 to $8.5 \mathrm{~m}$ apart were selected on a small slope with a steepness of approximately $21^{\circ}$ [27]. The number of branches for the three sample shrubs was 60 , 45 , and 53, respectively, and they were divided into five groups according to different basal diameters (9.00-10.00, 10.00-13.00, 13.00-17.00, 17.00-19.00, and 19.00-21.00 mm). Then, 16 branches with good growth status and representative rows were selected for measurement. The height, canopy, stem base diameter (SBD), stem length (SL), and primary branch numbers in the stems (PBN) of the sample branches were investigated (Table 1). The SHB [28] was used to measure SF with the Dynagage Flow 32-1K system (Dynamax, Houston, TX, USA) from July 28 to September 28, 2018. Sixteen gauges that could measure SF for stem diameters ranging from 9 to $21 \mathrm{~mm}$ were separately installed on 16 branches selected from the three C. korshinskii plants. Smooth G4 mix oil was used to maintain a close connection and prevent adhesion between the gauges and stems. To reduce the influences of solar radiation, air temperature, and humidity on the performance of the gauges, three layers of aluminum foil were coated on the outer layer of the gauges. The data transmission cables of the gauges were connected with the corresponding interface of the data collector (CR1000), and the power cord was connected with a $12 \mathrm{v}$ battery with solar panels. During the period of measurement, five branches were replaced with new branches due to abnormal data (Table 1). Once the abnormal data was eliminated, the normal data were analyzed, which came from 21 stems (including five new stems). The stem biomass was estimated using a statistical model (Equation (1)) that was established for the same species in a similar semiarid area on the Loess Plateau [29].

$$
\mathrm{W}=\beta_{1} \times\left(\mathrm{D}^{2} \times \mathrm{H}\right)^{\beta_{2}},
$$

where $W$ is the estimated stem biomass, $\beta_{1}$ and $\beta_{2}$ are estimated parameters of 0.0059 and 0.9686 , respectively, $\mathrm{D}$ is the base diameter, and $\mathrm{H}$ is the stem length.

Table 1. Morphological traits of the twenty-one stems used for the sap flow (SF) measurements for Caragana korshinskii Kom.

\begin{tabular}{|c|c|c|c|c|c|c|c|}
\hline Shrub No. & Stem No. & PBN & SL (cm) & SBD (mm) & W (g) & Height $(\mathrm{cm})$ & Canopy Size $(\mathrm{cm})$ \\
\hline \multirow[t]{7}{*}{1} & 1 & 5 & 153 & 10.0 & 77.8 & 310.0 & $410 \times 374$ \\
\hline & 2 & 6 & 215 & 9.7 & 103.5 & & \\
\hline & 3 & 12 & 175 & 11.2 & 115.9 & & \\
\hline & 4 & 9 & 195 & 11.5 & 84.4 & & \\
\hline & 5 & 7 & 240 & 13.4 & 104.9 & & \\
\hline & 6 & 13 & 232 & 16.6 & 71.3 & & \\
\hline & 7 & 7 & 260 & 19.4 & 111.6 & & \\
\hline \multirow[t]{6}{*}{2} & 8 & 12 & 195 & 10.8 & 91.9 & 280.0 & $340 \times 340$ \\
\hline & 9 & 8 & 155 & 10.3 & 99.7 & & \\
\hline & 10 & 11 & 157 & 10.7 & 92.5 & & \\
\hline & 11 & 12 & 195 & 13.4 & 128.9 & & \\
\hline & 12 & 14 & 228 & 16.6 & 213. 7 & & \\
\hline & 13 & 25 & 270 & 20.0 & 174.7 & & \\
\hline \multirow[t]{8}{*}{3} & 14 & 10 & 233 & 9.4 & 204.7 & 320.0 & $350 \times 330$ \\
\hline & 15 & 14 & 150 & 9.6 & 313.1 & & \\
\hline & 16 & 5 & 160 & 11.1 & 306.4 & & \\
\hline & 17 & 8 & 150 & 11.0 & 334.1 & & \\
\hline & 18 & 7 & 232 & 13.3 & 281.5 & & \\
\hline & 19 & 11 & 233 & 17.1 & 473.3 & & \\
\hline & 20 & 4 & 180 & 17.8 & 521.8 & & \\
\hline & 21 & 14 & 240 & 20.3 & 476.4 & & \\
\hline
\end{tabular}

Abbreviations: PBN, primary branch numbers in the stem; SL, stem length; SBD, stem base diameter; W, estimated stem biomass. Stem numbers 1, 2, 5, 9, and 12 were replaced with numbers 2, 4, 6, 10, and 13. 


\subsection{Soil Water Content Measurement}

Soil water contents (SWC) were measured 10 times at depths of up to $1.8 \mathrm{~m}$ in 20 -cm increments below the forest floor in each shrub using a time domain reflectometry (TDR) moisture measurement system (TRIME, IMKO Micromodultechnik, Ettlingen, Germany). Two Tecanat ${ }^{\circledR}$ plastic tubes $2 \mathrm{~m}$ in length and $42 \mathrm{~mm}$ in internal diameter were permanently placed in each shrub (approximately $30 \mathrm{~cm}$ away from the roots of the shrub) for repetitive TDR measurements. Measurements were made once per day from 16 September to 25 September.

\subsection{Measurement of Meteorological Variables}

Meteorological variables, including the solar radiation $\left(\mathrm{R}_{\mathrm{s}}, \mathrm{MJ} \cdot \mathrm{m}^{-2} \cdot \mathrm{d}^{-1}\right)$, photosynthetically active radiation $\left(\mathrm{PAR}, \mu \mathrm{mol} \cdot \mathrm{m}^{-2} \cdot \mathrm{s}^{-1}\right)$, mean air temperature $\left(\mathrm{T}_{\text {mean }},{ }^{\circ} \mathrm{C}\right)$, maximum air temperature $\left(\mathrm{T}_{\max },{ }^{\circ} \mathrm{C}\right)$, minimum air temperature $\left(\mathrm{T}_{\min },{ }^{\circ} \mathrm{C}\right)$, relative humidity $(\mathrm{RH}, \%)$, precipitation $(\mathrm{P}, \mathrm{mm})$, and wind velocity $\left(\mu, \mathrm{m} \cdot \mathrm{s}^{-1}\right)$, were obtained from an automated meteorological station approximately $1.2 \mathrm{~km}$ away from the study site.

The vapor pressure deficit (VPD, $\mathrm{kPa}$ ) was then calculated from $\mathrm{T}$ and $\mathrm{RH}$ following Equations (2) and (3) given by Campbell and Norman [30]. Additionally, considering that the influence of microclimate on SF means that vapor pressure accounts for more than two-thirds of total transpiration and solar radiation $\left(R_{s}\right)$ accounts for one-third of total transpiration, the variable of transpiration $\left(\mathrm{VT}, \mathrm{kPa}\left(\mathrm{W} \cdot \mathrm{m}^{-2}\right)^{1 / 2}\right.$ ) was calculated from the VPD and $\mathrm{R}_{\mathrm{s}}$ (Equation (4)) according to previous studies $[10,31,32]$.

$$
\begin{gathered}
\mathrm{e}_{\mathrm{s}}=0.611 \times \operatorname{EXP}\left(\frac{17.502 \times \mathrm{T}}{\mathrm{T}+240.97}\right), \\
\mathrm{VPD}=\mathrm{e}_{\mathrm{s}}-\frac{\mathrm{e}_{\mathrm{s}} \times \mathrm{RH}}{100}, \\
\mathrm{VT}=\mathrm{VPD} \times\left(\mathrm{R}_{\mathrm{s}}\right)^{\frac{1}{2}},
\end{gathered}
$$

Daily reference crop evapotranspiration $\left(\mathrm{ET} 0, \mathrm{~mm} \cdot \mathrm{d}^{-1}\right)$ was calculated using the Food and Agriculture Organization of the United Nations (FAO) Penman-Monteith Equation (5) [33]:

$$
\mathrm{ET}_{0}=\frac{0.408 \times \Delta\left(\mathrm{R}_{\mathrm{n}}-\mathrm{G}\right)+\gamma\left(\frac{900}{\mathrm{~T}+273}\right) \mu_{2}-\left(\mathrm{e}_{\mathrm{s}}-\mathrm{e}_{\mathrm{a}}\right)}{\Delta+\gamma\left(1+0.34 \mu_{2}\right)}
$$

where $\Delta$ is the vapor pressure curve slope $\left(\mathrm{kPa} \cdot{ }^{\circ} \mathrm{C}^{-1}\right), \mathrm{R}_{\mathrm{n}}$ is the net radiation at the plant surface $\left(\mathrm{MJ} \cdot \mathrm{m}^{-2} \cdot \mathrm{d}^{-1}\right), \mathrm{G}$ is the soil heat flux density $\left(\mathrm{MJ} \cdot \mathrm{m}^{-2} \cdot \mathrm{d}^{-1}\right), \gamma$ is a psychrometric constant $\left(\mathrm{kPa} \cdot{ }^{\circ} \mathrm{C}^{-1}\right)$, $\mathrm{T}$ is the mean daily air temperature at $2 \mathrm{~m}$ height $\left({ }^{\circ} \mathrm{C}\right), \mu_{2}$ is the wind speed at $2 \mathrm{~m}$ height $\left(\mathrm{m} \cdot \mathrm{s}^{-1}\right), \mathrm{e}_{\mathrm{s}}$ is the saturation vapor pressure $(\mathrm{kPa})$, and $\mathrm{e}_{\mathrm{a}}$ is the actual vapor pressure $(\mathrm{kPa})$. As the magnitude of the daily averaged soil heat flux density beneath the vegetation is relatively small, it can be ignored; therefore, $\mathrm{G} \approx 0[9]$.

\subsection{Model Establishment and Validation}

The measured data of plant morphology and SF were divided into two parts. Seventy percent of the data (i.e., 14 stems) were used to build the stem-scale SF estimation models, and the remaining $30 \%$ of the data (i.e., 7 stems) were used to validate the model. The performance of the model was evaluated using the coefficient of determination $\left(R^{2}\right)$, root mean squared error (RMSE), and mean error (ME), which were calculated as follows [34]:

$$
R^{2}=1-\frac{\sum_{\mathrm{i}=1}^{n}\left(\mathrm{y}_{\mathrm{i}}-\hat{\mathrm{y}}_{\mathrm{i}}\right)^{2}}{\sum_{\mathrm{i}=1}^{n}\left(\mathrm{y}_{\mathrm{i}}-\overline{\mathrm{y}}_{\mathrm{i}}\right)^{2}}
$$




$$
\begin{aligned}
\text { RMSE } & =\sqrt{\frac{\sum_{i=1}^{\mathrm{n}}\left(\mathrm{y}_{\mathrm{i}}-\hat{\mathrm{y}}_{\mathrm{i}}\right)^{2}}{\mathrm{n}}}, \\
\mathrm{ME} & =\frac{\sum_{\mathrm{i}=1}^{\mathrm{n}}\left(\mathrm{y}_{\mathrm{i}}-\hat{\mathrm{y}}_{\mathrm{i}}\right)}{\mathrm{n}},
\end{aligned}
$$

where $\mathrm{n}$ is the number of stems measured, $\mathrm{y}_{\mathrm{i}}$ is the measured value of $\mathrm{SF}, \hat{\mathrm{y}}_{\mathrm{i}}$ is an estimated value of $\mathrm{SF}$, and $\bar{y}_{\mathrm{i}}$ is the mean of the measured values.

\subsection{Data Analysis}

The stem heat balance method was described in detail by Kigalu [35], which was calculated briefly as follows:

$$
\begin{gathered}
Q_{f}=P_{\text {in }}-Q_{c d}-Q_{r}+Q_{s}, \\
F=\frac{\left(P_{\text {in }}-Q_{c d}-Q_{r}+Q_{s}\right)}{\left(C_{s} \times d T_{\text {sap }}\right)}, \\
\mathrm{dT}_{\text {sap }}=\frac{\left(\mathrm{dT}_{\mathrm{a}}+\mathrm{dT}_{\mathrm{b}}\right)}{2},
\end{gathered}
$$

where $Q_{f}$ is the amount of heat $(W)$ transported in the moving sap, $P_{\text {in }}$ is the heater power input $(\mathrm{W}), \mathrm{Q}_{\mathrm{cd}}$ is the heat conduction loss along the stem up- and downstream $(\mathrm{W}), \mathrm{Q}_{\mathrm{r}}$ is the radial heat conduction loss $(\mathrm{W}), \mathrm{Q}_{\mathrm{s}}$ is the heat stored in the stem section $(\mathrm{W}), \mathrm{F}$ is sap flow velocity $\left(\mathrm{kg} \cdot \mathrm{m}^{-2} \cdot \mathrm{h}^{-1}\right)$, $\mathrm{C}_{\mathrm{s}}$ is the specific heat capacity of the sap or water $\left(4.186 \mathrm{~J} \cdot \mathrm{g}^{-1} \cdot{ }^{\circ} \mathrm{C}^{-1}\right), \mathrm{dT}_{\text {sap }}$ is the mean temperature between the heater and the stem section $\left({ }^{\circ} \mathrm{C}\right)$, and $\mathrm{dT}_{\mathrm{a}}$ and $\mathrm{dT}_{\mathrm{b}}$ are temperature differentials of the sap up- and downstream measured by thermocouples $a$ and $b$, respectively.

Descriptive statistics were compiled for the plant morphological characteristics (height, canopy size, PBN, SL, SBD, and W). We analyzed the hysteresis effect based on the relationship between the $0.5 \mathrm{~h}$ average SF of 21 branches and the $0.5 \mathrm{~h}$ meteorological factors (T, VPD, VT, PAR, $\mathrm{ET}_{0}$ ). The average SF per hour and the average value of meteorological factors during the day were used to analyze the relationship between SF and meteorological factors. Linear regression was used to quantify the specific relationships between stem-scale SF and the plant morphological traits for the three individual plants. Origin 9.0 software for Windows (Origin Software Inc., Fairview, TX, USA) and SPSS 21.0 software for Windows (SPSS Inc., Chicago, IL, USA) were used to draw the figures and for the statistical analyses, respectively.

\section{Results and Discussion}

\subsection{Diurnal Variations in Sap Flow}

Sap flow had a sharp increase near 08:00, peaked at 14:30, and then decreased gradually down to the same level that was recorded before 08:00. The peak time of T and VPD were nearly same, and both lagged behind that of SF by $0.5 \mathrm{~h}$ (Figure 3a,c). The sharp increase of SF in the morning lagged behind in PAR by $2.0 \mathrm{~h}$, and the peak time of SF lagged behind in PAR by $2.5 \mathrm{~h}$ (Figure 3b). The increase of SF in the morning was similar to that of VT, and the decrease of SF in the afternoon slightly lagged behind the decrease of VT. Sap flow then decreased to remain stable, lagging behind VT by $1.0 \mathrm{~h}$ (Figure 3d). The diurnal lag effects between SF and the meteorological factors and the diurnal hysteresis loops of SF are plotted in Figure 4. The direction of change with time tracked clockwise hysteresis for VPD, and the variation in VPD lagged behind that in SF (Figure 4c). The averaged relationship between SF with PAR and VT in a day revealed a hysteresis loop with a counter-clockwise rotation (Figure 4b,d), indicating that the variation in SF lagged behind those in PAR and VT. 

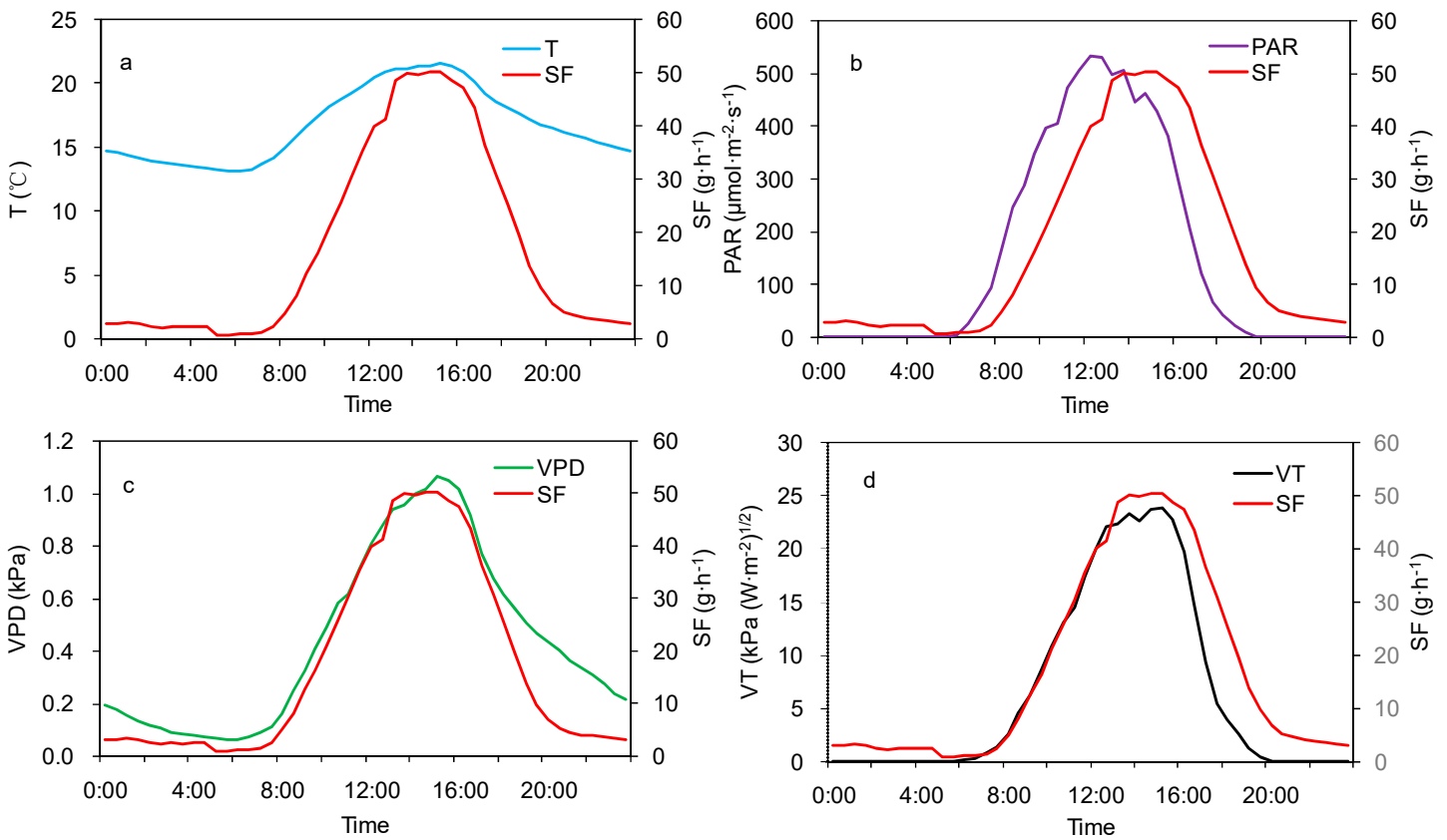

Figure 3. Diurnal variations in SF, (a) air temperature (T), (b) photosynthetically active radiation (PAR), (c) vapor pressure deficit (VPD), and (d) variable of transpiration (VT) for the whole measuring period.
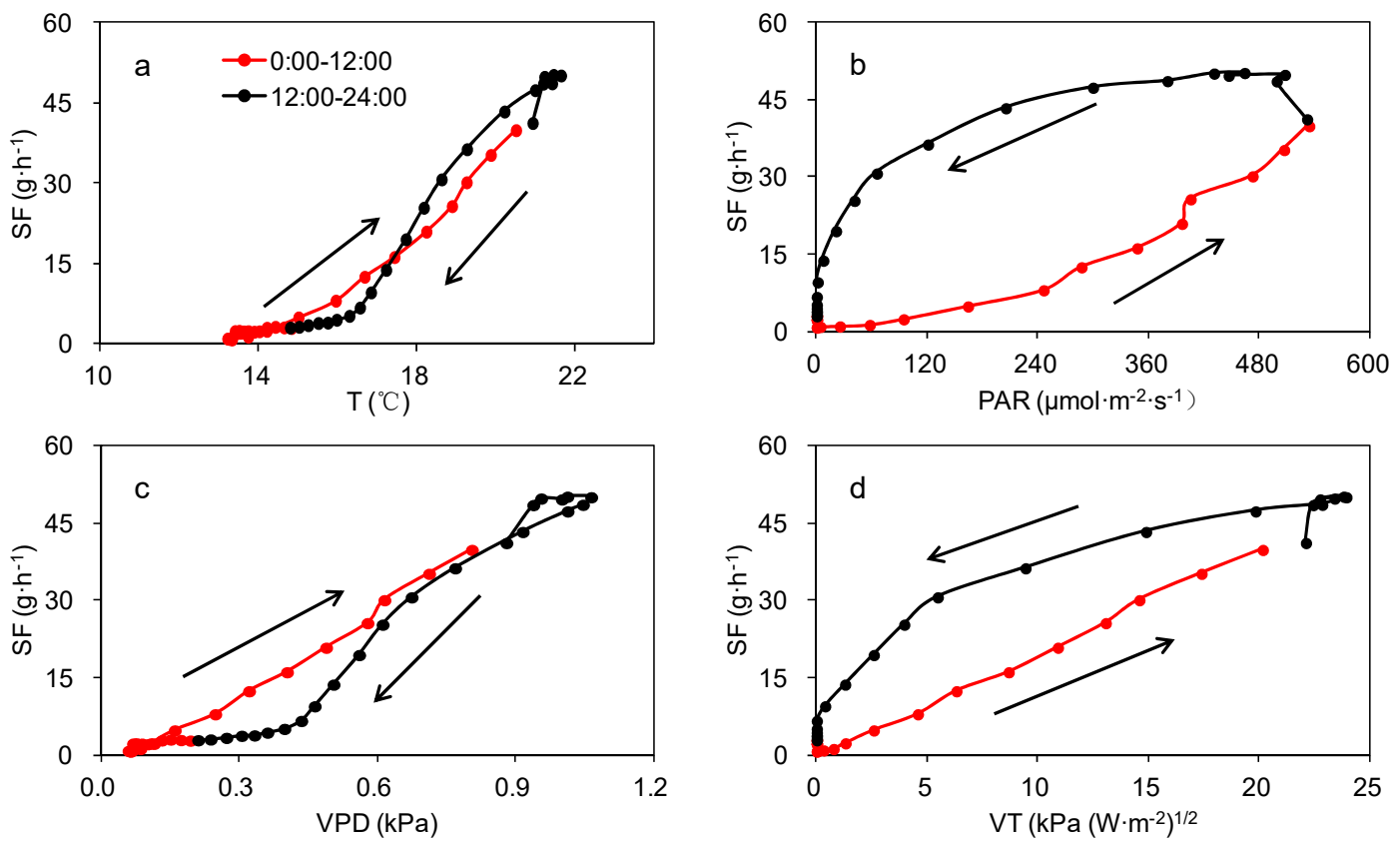

Figure 4. Hysteresis loops between the 0.5-hourly mean SF and (a) air temperature (T), (b) photosynthetically active radiation (PAR), (c) vapor pressure deficit (VPD), and (d) variable of transpiration (VT). Note that the arrows on the plots denote the sap flow change direction with time.

The observed hysteresis between SF, radiation, and VPD was consistent with other studies [9,36-38]. Note that SF sometimes declines with increasing VPD and solar radiation in the short term, suggesting the effect of stomatal regulation on transpiration [39]. In the early morning and late-night periods, SF apparently increased at low VPD levels. However, it has been pointed out that a time lag usually occurs at this time scale, and the lag is no longer obvious when scaled up to the day scale or longer time scales [40]. In this study, it seemed that at the diurnal scale, C. korshinskii had the maximum rate of SF when the VPD, PAR, and T were not particularly high. On the other hand, 
favorable meteorological conditions for transpiration (i.e., higher PAR, VPD, and T levels) prevented further increases in SF. Therefore, the diurnal hysteresis between the peaks of SF and the meteorological variables was a self-protection mechanism to avoid C. korshinskii overlaps with peak SF times and peak meteorological variables that prevent excessive water extraction from the stems. This mechanism prevented xylem vessel embolism, causing the collapse of the hydrological conductive system of the xylem, and this response is also a conservative water use strategy of C. korshinskii for meteorological drivers [41]

\subsection{Effect of Meteorological Factors on SF}

Several studies have reported a close relationship between SWC and SF for a variety of tree species $[16,19,40]$. The results of regression analysis between SWC and SF are shown in Figure A1. However, we observed that there was no close relation between them in our study, and this result agrees well with the findings of Ma et al. [41] and Hornal et al. [42]. Ford et al. [43] concluded that tree transpiration is only limited by SWC for most forests when soil moisture is severely deficient. In this study, the experimental periods were mainly restricted in the humid, rainy seasons. The observed poor correlation between SF and SWC suggests that SWC in the 0-180 cm soil depth range was not a limiting factor on SF. It also could be attributed to that fact that C. korshinskii used SWC from the soil layer that is deeper than $180 \mathrm{~cm}$ [44]; however, this was not monitored in our study. Further study is justified to clarify the correlation between SF and deep SWC in both dry and rainy seasons.

Schultz et al. [45] considered that the hydrological process of tree transpiration is dominated by the evaporative demand and available energy, and it is often limited by water availability. Several studies have indicated that VPD, T, and radiation are the most important environmental factors controlling $\mathrm{SF}$, especially VPD and radiation $[32,46,47]$. Therefore, we used PAR as a representative of the radiation factor in this study. Tie et al. [9] considered that radiation factor was the key environmental factor controlling SF, and found that the whole levels of VPD, T, PAR, and sap flux density were all significantly higher under the high radiation condition $\left(\mathrm{PAR}>231.48 \mu \mathrm{mol} \cdot \mathrm{m}^{-2} \cdot \mathrm{s}^{-1}\right.$ ) than under the low radiation condition (PAR $<231.48 \mu \mathrm{mol} \cdot \mathrm{m}^{-2} \cdot \mathrm{s}^{-1}$ ). To remove the effect of PAR on the VPD component, we normalized SF with PAR to further analyze the relationship between VPD and SF residuals. The residual analysis showed linear and positive relationships between SF and VPD (Figure A2).

The meteorological variables showed a decreasing tendency during the measuring period and shared similar varying tendencies with SF (Figure A3). The regression analysis further indicated that all of the meteorological variables (T, PAR, VPD, VT, and $\mathrm{ET}_{0}$ ) were linearly and positively correlated with $\mathrm{SF}$ (Figure 5). The different $R^{2}$ values in the regression models in Figure 5 indicate that meteorological factors had a variable control on SF. Specifically, SF had the weakest correlation with T (Figure 5) but had the strongest correlation with VPD (Figure 5).

These results suggest quite different controls of environmental factors on SF. In our study, VPD and $\mathrm{ET}_{0}$ were the two main meteorological factors affecting SF, which were similar to those of other studies [11,44]. Our data indicated that VPD, VT, and $\mathrm{ET}_{0}$ explained more of the variations in SF than T and PAR, and VPD was more closely correlated with SF than PAR and T. Plant transpiration becomes stronger with increasing VPD levels, which also has a direct influence on stem SF. Similarly, VT is determined by VPD and $R_{s}$. The effects of $R_{s}$ on transpiration water consumption by plants include temperature and PAR. As the intensity of solar radiation increases, the temperature on the surfaces of plant leaves will also increase. Additionally, visible light controls the opening and closing of stomata, and in general, the stomata of most C. korshinskii plants close in the absence of light [11]. Photosynthetically active radiation can be a good representative radiation factor in the analysis of SF because PAR principally reflects the part of radiation used for photosynthesis, and SF is closely related to photosynthetic processes [33]. The observed diurnal variations in SF were mainly due to the large solar radiation intensity and temperature differences between day and night in semiarid areas [12]. 

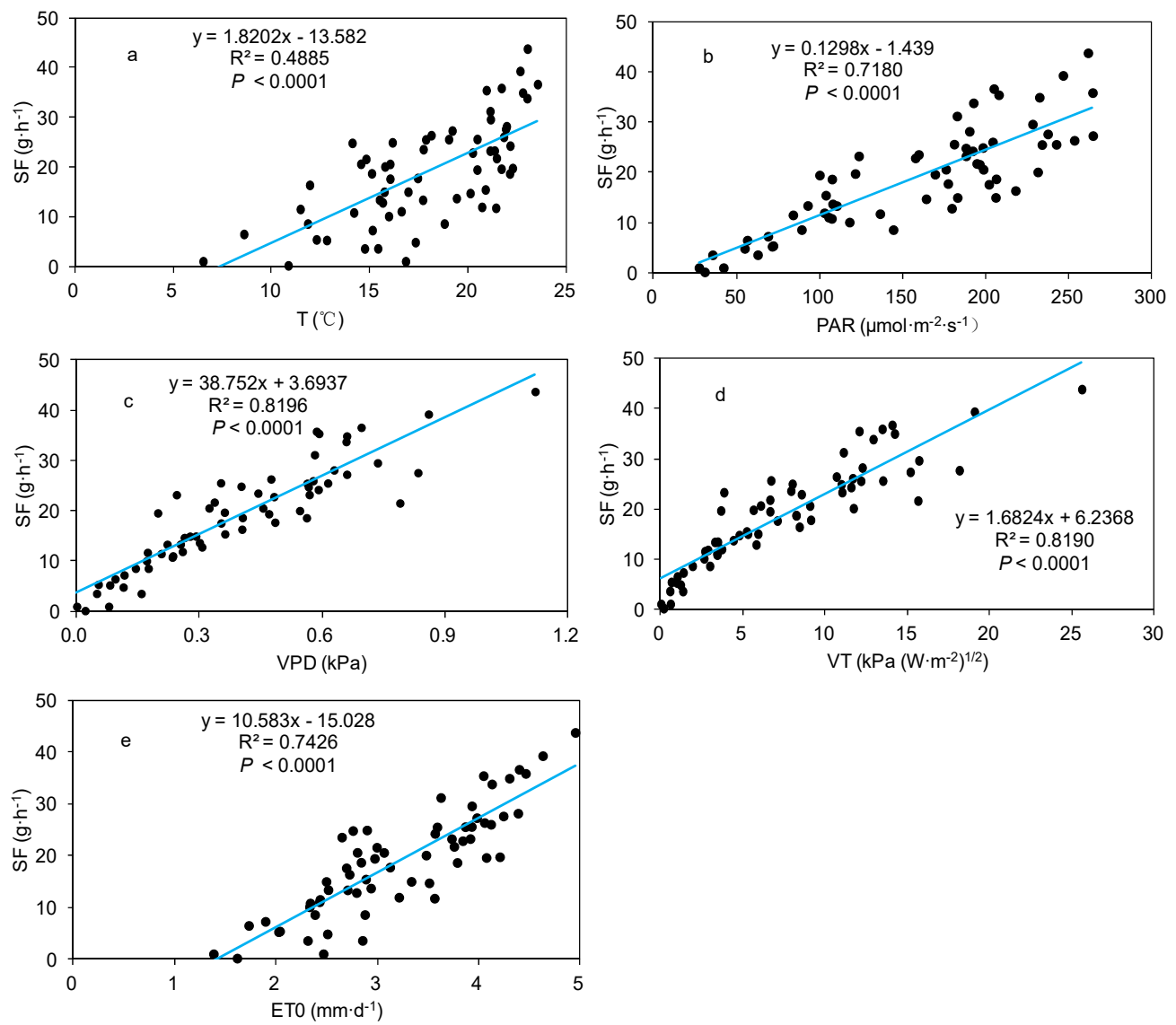

Figure 5. Regression relations between daily SF and (a) air temperature (T), (b) photosynthetically active radiation (PAR), (c) vapor pressure deficit (VPD), (d) variable of transpiration (VT), and (e) reference evapotranspiration $\left(\mathrm{ET}_{0}\right)$.

\subsection{Effect of Morphological Traits on Stem-Scale SF}

Morphology is an important factor affecting SF in plant trunks. In our study, we observed that the stem-scale SF differed notably with the SBD despite sharing the same diurnal variation (Figure A4). Summarizing the different categories of plant morphological variables (Figure 6), the stem-scale SFs were significantly largest $(p<0.05)$ in the largest levels of PBN $(18-25)$, SL $(230-270 \mathrm{~cm})$, SBD $(17-21 \mathrm{~mm})$, and W (350-550 g), followed by those in the middle levels of PBN (11-18), SL (190-230 cm), SBD (13-17 mm), and W (200-350 g), and lastly followed by those in the smallest levels of PBN (4-11), SL (150-190 cm), SBD (9-11 mm), and W (50-200 g). The regression analysis further indicated that the stem-scale SF of C. korshinskii had significantly positive linear correlations with PBN (Figure 7a), SL (Figure 7b), SBD (Figure 7c), and W (Figure 7d) $(p<0.001$ ).

The increase of SF during the morning was stronger at larger SBD and had an apparent single peak diurnal curve (Figure 7), suggesting that there was no noon depression in any stem size. This result was similar with the finding in C. korshinskii and A. ordosica reported by Xia et al. [48], Huang et al. [12], and Chen et al. [32]. Sapwood area is considered an important metric for scaling up individual plant water consumption to stand water consumption [38,49,50]; therefore, knowing that plants with different stem diameters have different $\mathrm{SF}$ rates is especially important because caution should be taken when using branch and basal trunk sap flow measurements to estimate whole-plant water capacity [51]. 

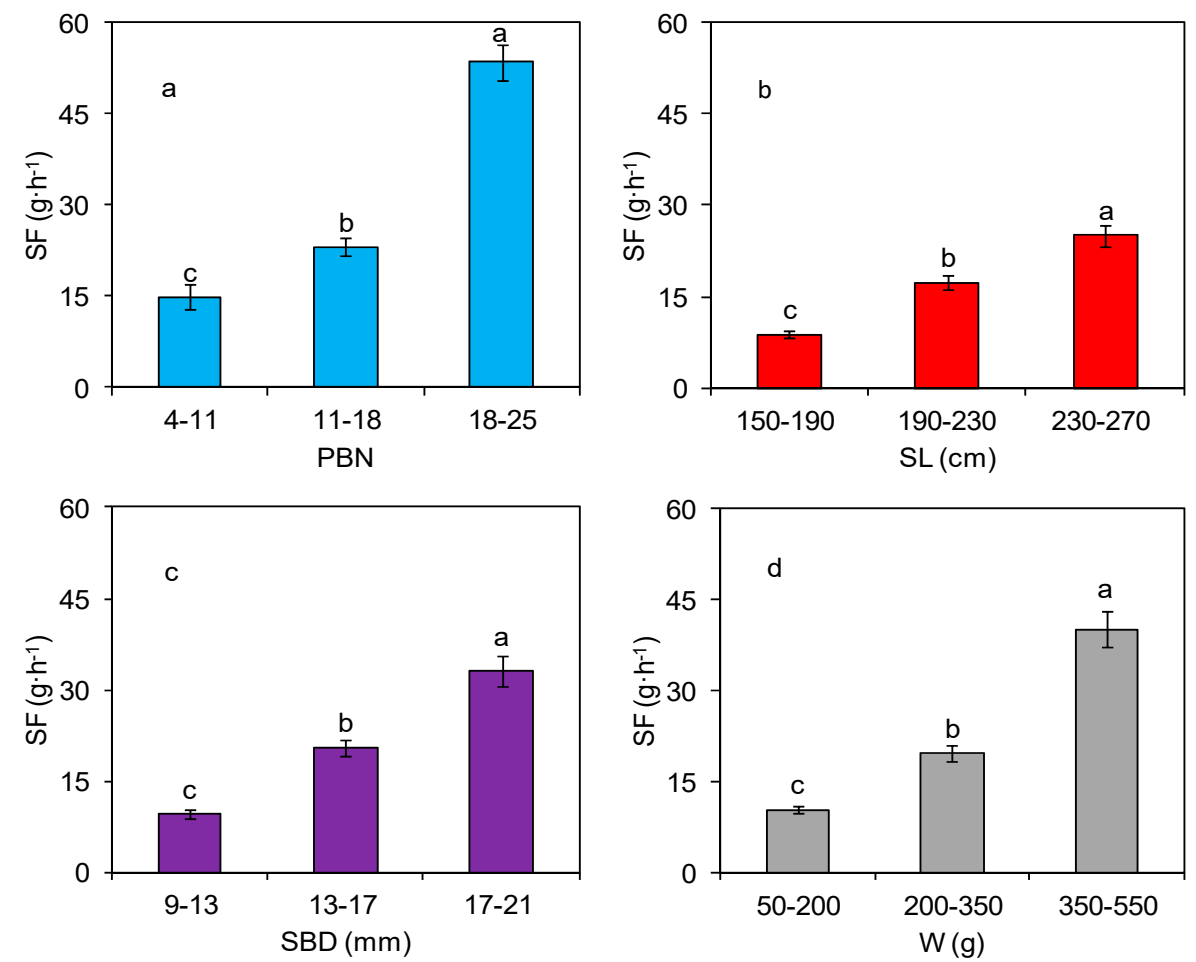

Figure 6. Comparison of the average stem-scale sap flow (SF) for different categories of (a) primary branch numbers (PBN), (b) stem length (SL), (c) stem base diameter (SBD), and (d) estimated stem biomass $(\mathrm{W})$. The different lower-case letters in the figure indicate significant differences at $p<0.05$ using the least significant difference (LSD) method.
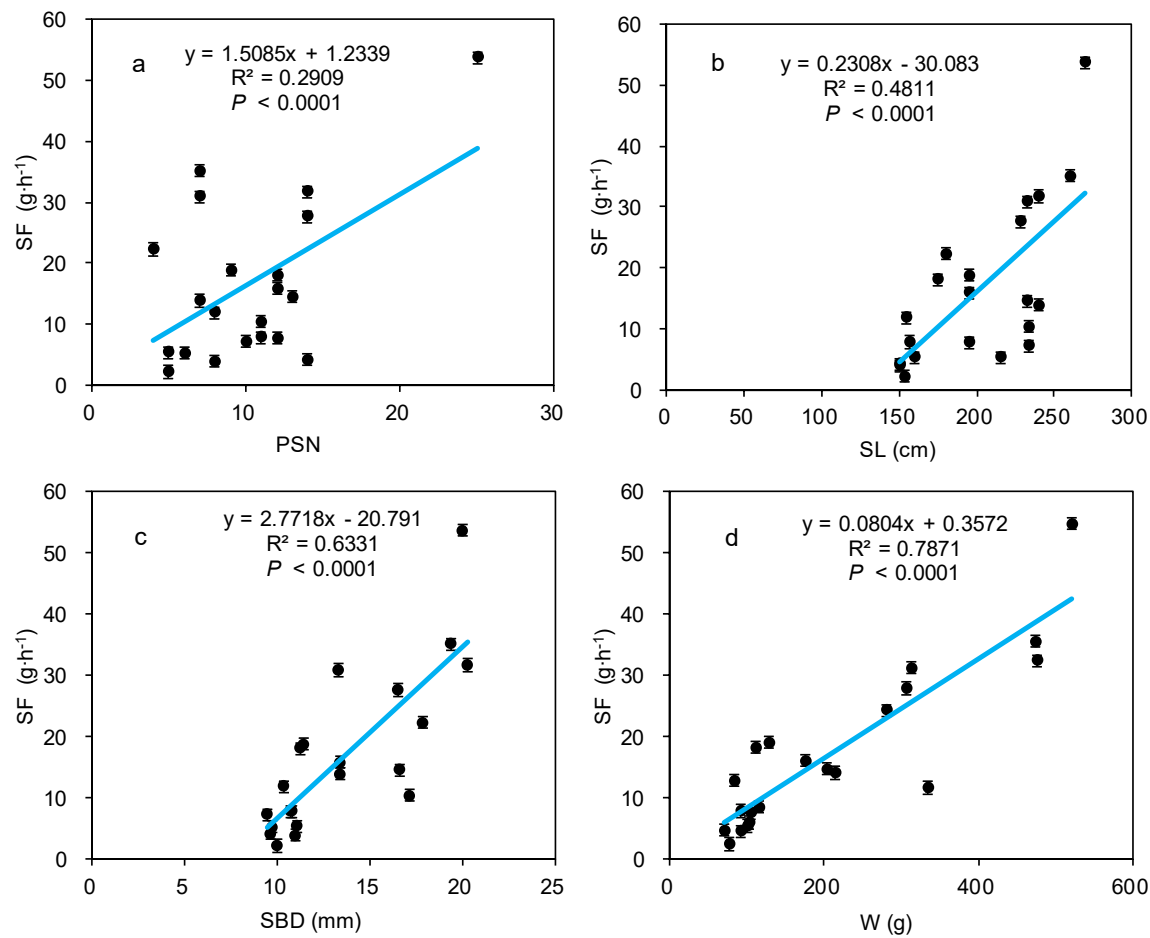

Figure 7. Regression relationships between the stem-scale SF and stem morphological traits. 


\subsection{Established Models for Estimating Stem-Scale SF and Its Validation}

The established multivariate linear regression models between stem-scale $\mathrm{SF}$ and stem morphological variables are shown in Table 2. The results show that the SBD-based model (No. 10) had a satisfactory $R^{2}$ value (0.8046), and most importantly, all of its regression coefficients were statistically significant $(p<0.05)$. The validation dataset further indicated good agreement between the measured and estimated $S F$ values, as indicated by the high $R^{2}$ value (0.9726) and low RMSE (2.5389) and ME (6.4460) values (Figure 8). We further scaled up SF from the stem scale to the individual scale using the established model and the measured SBD data for all the stems. The results indicated that the individual-scale SF averaged 1111.7, 528.7, and $789.9 \mathrm{~g} \cdot \mathrm{h}^{-1}$ for the three C. korshinskii plants during the intensive rainfall study period. Over the canopy projection area, the average water use of $C$. korshinskii was $1.91,1.10$, and $1.59 \mathrm{~mm} \cdot \mathrm{d}^{-1}$ for the three C. korshinskii plants (Table 3).

Our results were comparable with previous findings. Huang et al. [52] reported that the daily transpiration rates of C. korshinskii and A. ordosica communities were 0.36 and $0.28 \mathrm{~mm} \cdot \mathrm{d}^{-1}$, respectively, during the growing season (April-October) in the central part of Western China. The higher water use in our study might be attributed to the stronger growth period of $C$. korshinskii and the larger rainfall input $(177.8 \mathrm{~mm})$, which differed from the previous study $(125.2-127.4 \mathrm{~mm})$. Zhang et al. [53] found that stand transpiration of black locust averaged $0.49,0.33$, and $0.32 \mathrm{~mm} \cdot \mathrm{d}^{-1}$ during the growing seasons, respectively, with maximum values of $1.07,0.74$, and $0.90 \mathrm{~mm} \cdot \mathrm{d}^{-1}$ for the whole measuring period in Shanxi Province. McJannet et al. [54] reported that the canopy transpiration rates ranged from 2.2 to $3.8 \mathrm{~mm} \cdot \mathrm{d}^{-1}$ in North Queensland, and canopy transpiration rates of conifer stand ranged from 0.4 to $1.5 \mathrm{~mm} \cdot \mathrm{d}^{-1}$, with a mean value of $0.9 \mathrm{~mm} \cdot \mathrm{d}^{-1}$ [55]. The SF value predicted in our study $\left(1.10-1.91 \mathrm{~mm} \cdot \mathrm{d}^{-1}\right)$ is comparable to that in previous studies. Estimating transpiration water use for individual trees is usually achieved by multiplying the average stand SF by the total sapwood area of the stand [13,17-19]. Shrubs, however, typically have many branches, and their basal diameter is small. Zha et al. [19] estimated stem-scale SF for A. ordosica by measuring the SF per leaf area, total leaf area per stem, and the number of stems. The authors then determined the transpiration amount per stand by the stem-scale SF and the leaf area index of shrubs. Huang et al. [13] calculated plant canopy transpiration for C. korshinskii and A. ordosica using the same method. In this study, we established a regression model between stem SF and the SBD of $C$. korshinskii. The established SF estimation model in our study may have limitations if the model is used to estimate SF of $C$. korshinskii in the water-limited dry season. However, this method has several advantages-it is relatively easy to use, continuous monitoring can occur over a period of time that is as short as necessary, the measurements do not modify the environment, and the method is nondestructive to the plants [17]. Additionally, the SF of branches with different base diameters can be accurately measured. Combined with the growth of branches, we can also calculate the water use efficiency and water use strategy of vegetation. In addition, plants with a low stem porosity, high transpiration rate, and multiple lateral branches, such as A. ordosica and C. korshinskii, are particularly suitable for the application of this method [12]. 
Table 2. Established linear regression models between sap flow and stem morphological variables using $70 \%$ of the whole dataset.

\begin{tabular}{|c|c|c|c|c|c|c|c|c|c|c|c|c|}
\hline No. & Function & $R^{2}$-adj & $p$ & $p_{c o n}$ & $p_{P B N}$ & $p_{S L}$ & $p_{S B D}$ & $p_{W}$ & VIF $_{\text {PBN }}$ & VIF $_{S L}$ & $\mathrm{VIF}_{\mathrm{SBD}}$ & $\mathrm{VIF}_{\mathrm{W}}$ \\
\hline 1 & $\mathrm{SF}=0.166 \mathrm{PBN}-0.012 \mathrm{SL}+0.069 \mathrm{~W}+1.691$ & 0.766 & $<0.0001$ & 0.880 & 0.688 & 0.879 & & 0.007 & 1.112 & 3.143 & 2.956 & \\
\hline 2 & $\mathrm{SF}=0.229 \mathrm{PBN}+0.034 \mathrm{SL}+2.233 \mathrm{SBD}-24.086$ & 0.766 & $<0.0001$ & 0.009 & 0.582 & 0.605 & 0.007 & & 1.097 & 4.354 & & 4.163 \\
\hline 3 & $\mathrm{SF}=0.151 \mathrm{PBN}+0.067 \mathrm{~W}+0.119$ & 0.541 & $<0.0001$ & 0.977 & 0.693 & & & $<0.0001$ & 1.079 & & & 1.079 \\
\hline 4 & $\mathrm{SF}=0.293 \mathrm{PBN}+2.517 \mathrm{SBD}-21.931$ & 0.781 & $<0.0001$ & 0.004 & 0.448 & & $<0.0001$ & & 1.015 & & 1.015 & \\
\hline 5 & $\mathrm{SF}=-0.007 \mathrm{PBN}+0.212 \mathrm{SL}-25.610$ & 0.781 & 0.005 & 0.031 & 0.990 & 0.002 & & & 1.032 & 1.032 & & \\
\hline 6 & $\mathrm{SF}=0.045 \mathrm{SL}+2.169 \mathrm{SBD}-23.089$ & 0.781 & $<0.0001$ & 0.007 & & 0.464 & 0.005 & & 2.868 & & 2.868 & \\
\hline 7 & $\mathrm{SF}=-0.004 \mathrm{SL}+0.068 \mathrm{~W}+2.033$ & 0.784 & $<0.0001$ & 0.849 & & 0.954 & & 0.005 & & 4.096 & & 4.096 \\
\hline 8 & $\mathrm{SF}=1.0 .597 \mathrm{PBN}+9.570$ & 0.036 & 0.473 & 0.271 & 0.473 & & & & 1.000 & & & \\
\hline 9 & $\mathrm{SF}=0.218 \mathrm{SL}-25.644$ & 0.579 & 0.001 & 0.020 & & 0.001 & & & & 1.000 & & \\
\hline 10 & $\mathrm{SF}=2.552 \mathrm{BD}-19.586$ & 0.788 & $<0.0001$ & 0.002 & & & $<0.0001$ & & & & 1.000 & \\
\hline 11 & $\mathrm{SF}=0.0767 \mathrm{~W}+7.429$ & 0.802 & $<0.0001$ & 0.542 & & & & $<0.0001$ & & & & 1.000 \\
\hline
\end{tabular}

Note: $p_{c o n}, p_{P B N}, p_{S L}, p_{S B D}$, and $p_{W}$ represent $p$ values of the regression coefficients of constant, PBN, SL, SBD, and W, respectively. VIF $F_{P B N}, V I F_{S L}, V I F_{S B D}$, and $V I F_{W}$ represent variance inflation factor values (VIF) of the regression coefficients of PBN, SL, SBD, and W, respectively. 


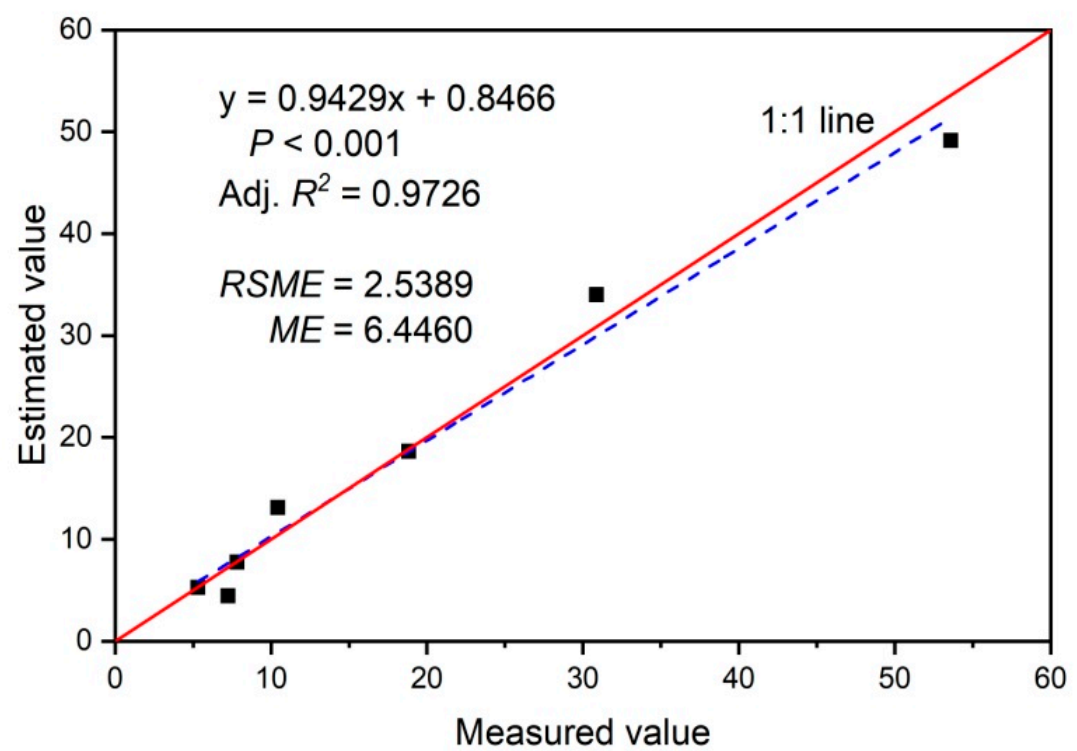

Figure 8. Comparison of the measured and estimated SF values using the remaining $30 \%$ of the validation dataset.

Table 3. Estimation of individual-scale SF for the three C. korshinskii plants.

\begin{tabular}{cccccc}
\hline SF & Shrub 1 & Shrub 2 & Shrub 3 & Average & SD \\
\hline $\mathrm{SF}\left(\mathrm{g} \cdot \mathrm{h}^{-1}\right)$ & 1111.71 & 528.73 & 789.86 & 810.10 & 195.89 \\
$\mathrm{SF}\left(\mathrm{mm} \cdot \mathrm{d}^{-1}\right)$ & 1.91 & 1.10 & 1.59 & 1.53 & 0.22 \\
\hline
\end{tabular}

\section{Conclusions}

Sap flow (SF) is typically measured only at the stem scale for multibranched shrub species, which limits the overall evaluation of plant water use on individual scales. In the present study, we explored suitable regression models for stem sap flow (SF) and stem morphological parameters and scaled up SF from the stem scale to the individual scale for Caragana korshinskii, a dominant shrub species on the Chinese Loess Plateau, from July to September 2018 in the rainy season. The results indicated that stem-scale SF was significantly and positively correlated with stem base diameter (SBD), stem length (SL), primary branch numbers in the stem (PBN), and estimated stem biomass (W). The SBD-based statistical model (SF $=2.552 \mathrm{SBD}-19.586)$ performed better than the models established using other plant morphological variables. Thus, this model can be used to scale up SF of C. korshinskii from the stem scale to the individual scale in the rainy season. However, the SF model that was established for the rainy season could perhaps be restricted when used to estimate SF of C. korshinskii in the water-limited dry season. Our model, we believe, has still made much progress in the rapid and accurate estimation of SF for $C$. korshinskii and also similar multibranched shrub species on the Chinese Loess Plateau. Future study is justified to focus on the establishment of an integrated SF estimation model for both dry and rainy seasons.

Author Contributions: G.W., Y.S., and X.Y. conceived and designed the experiments. G.W. and Z.C. performed the experiments. G.W. analyzed the data. B.M. contributed technical advice and collected meteorological data. G.W., Y.S., and X.Y. wrote the paper.

Funding: This research was funded by the National Key Research and Development Plan (No. 2017YFC0504603), the National Natural Science Foundation of China (No. 41701241), and the Fundamental Research Funds for the Central Universities (No. lzujbky-2019-34). And the APC was funded by No. 2017YFC0504603.

Acknowledgments: We are grateful to Wene Zhang, Yuliang Zhao, Bo Zhang, Miaoying Li, and Xingfa Lai for their contributions to this study.

Conflicts of Interest: The authors declare no conflict of interest. 


\section{Appendix A}
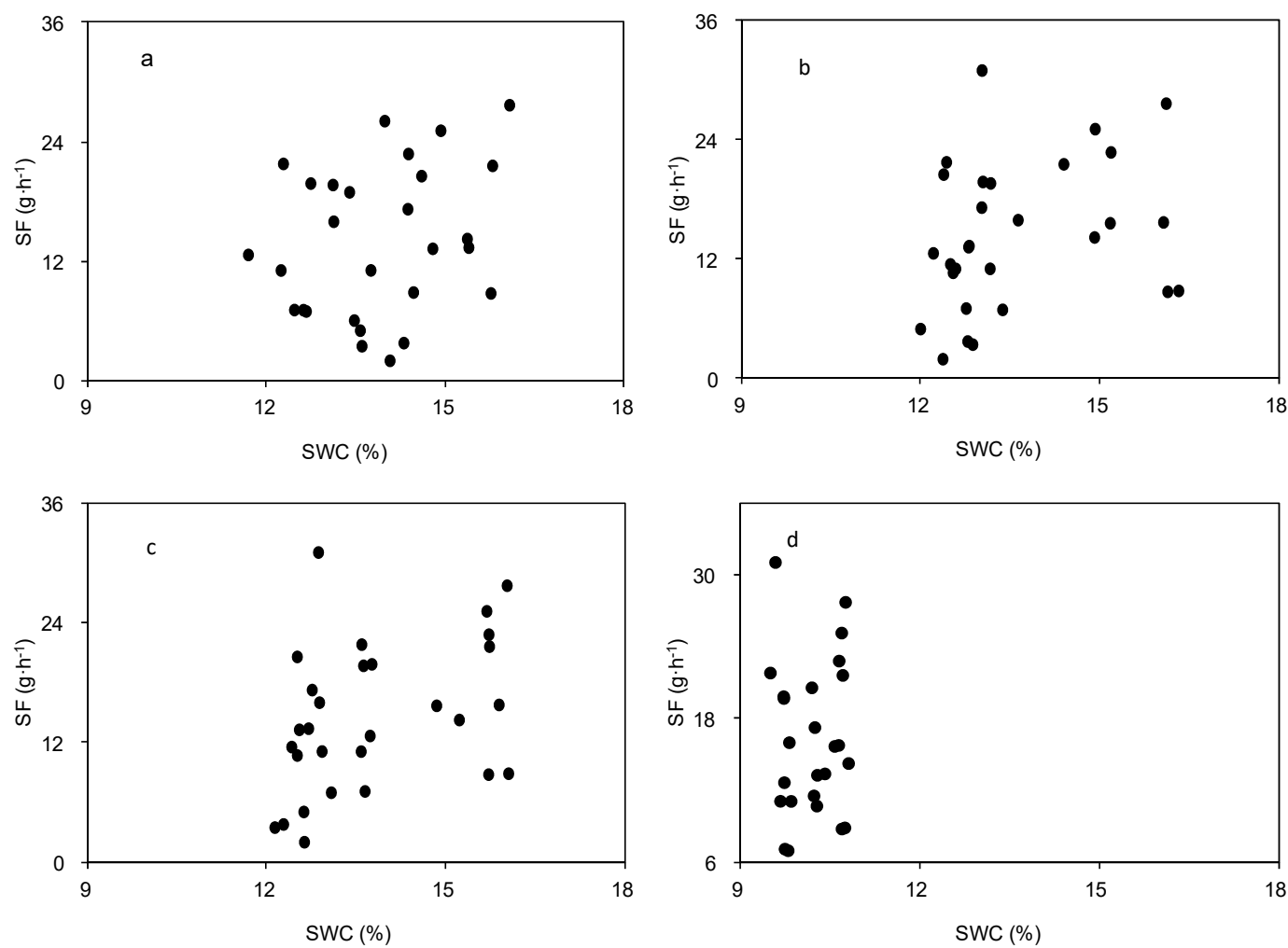

Figure A1. Relationship between SF and soil water content: (a) 0-40 cm; (b) 40-80 cm; (c) 80-120 cm; (d) $120-180 \mathrm{~cm}$.

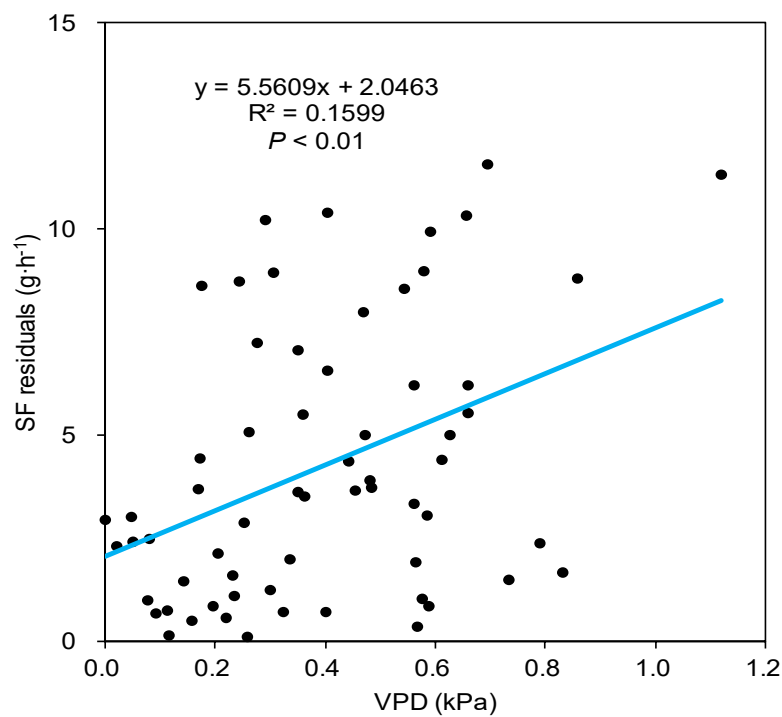

Figure A2. Regression relationships between the daily SF residuals and VPD. 

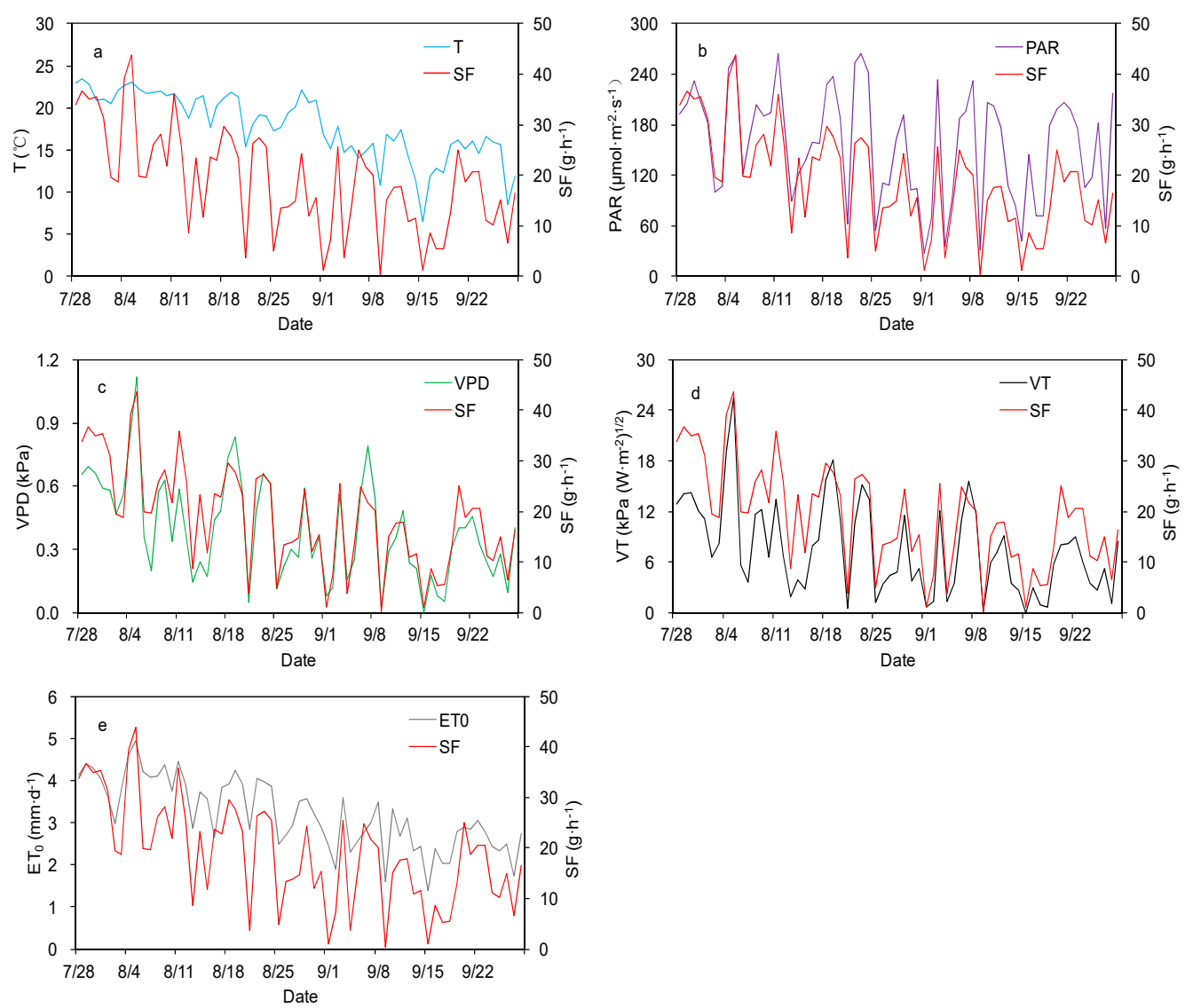

Figure A3. Dynamics of sap flow (SF) for (a) air temperature (T), (b) photosynthetically active radiation (PAR), (c) vapor pressure deficit (VPD), (d) variable of transpiration (VT), and (e) reference evapotranspiration $\left(\mathrm{ET}_{0}\right)$.

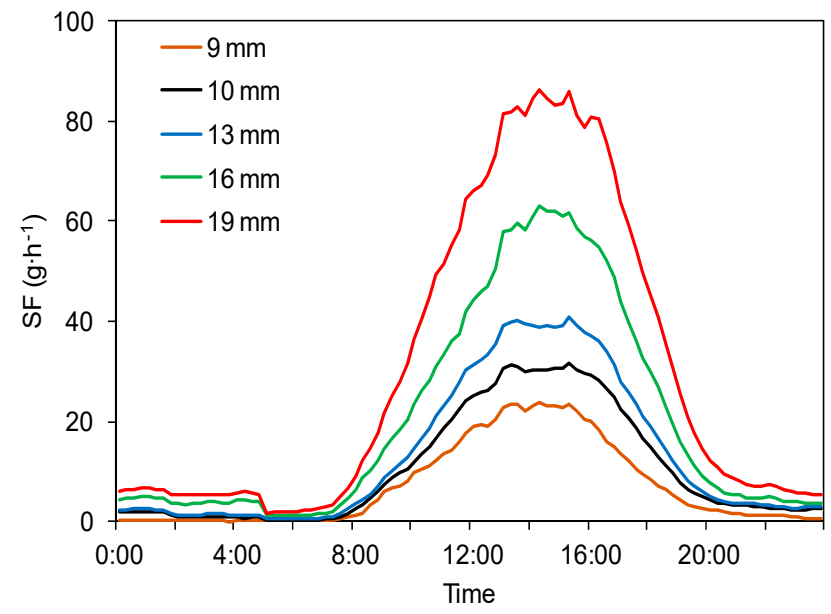

Figure A4. The daily variation in stem-scale SF for different stem base diameters for the whole measuring period.

\section{References}

1. Potts, D.L.; Huxman, T.E.; Cable, J.M.; English, N.B.; Ignace, D.D.; Eilts, J.A.; Mason, M.J.; Weltzin, J.F.; Williams, D.G. Antecedent moisture and seasonal precipitation influence the response of canopy-scale carbon and water exchange to rainfall pulses in a semi-arid grassland. New Phytol. 2010, 170, 849-860. [CrossRef] [PubMed] 
2. Wilson, K.B.; Hanson, P.J.; Mulholland, P.J.; Baldocchi, D.D.; Wullschleger, S.D. A comparison of methods for determining forest evapotranspiration and its components: Sap-flow, soil water budget, eddy covariance and catchment water balance. Agric. For. Meteorol. 2001, 106, 153-168.

3. Small, E.E.; Mcconnell, J.R. Comparison of soil moisture and meteorological controls on pine and spruce transpiration. Ecohydrology 2010, 1, 205-214. [CrossRef]

4. Sun, S.J.; Meng, P.; Zhang, J.S.; Wan, X.; Zheng, N.; He, C. Partitioning oak woodland evapotranspiration in the rocky mountainous area of North China was disturbed by foreign vapor, as estimated based on non-steady-state $18 \mathrm{O}$ isotopic composition. Agric. For. Meteorol. 2014, 184, 36-47. [CrossRef]

5. Kume, T.; Takizawa, H.; Yoshifuji, N.; Tanaka, K.; Tantasirin, C.; Tanaka, N.; Suzuki, M. Impact of soil drought on sap flow and water status of evergreen trees in a tropical monsoon forest in northern Thailand. For. Ecol. Manag. 2007, 238, 220-230. [CrossRef]

6. Miner, G.L.; Ham, J.M.; Kluitenberg, G.J. A heat-pulse method for measuring sap flow in corn and sunflower using 3D-printed sensor bodies and low-cost electronics. Agric. For. Meteorol. 2017, 246, 86-97. [CrossRef]

7. Ghimire, C.P.; Lubczynski, M.W.; Bruijnzeel, L.A.; Chavarro-Rincón, D. Transpiration and canopy conductance of two contrasting forest types in the Lesser Himalaya of Central Nepal. Agric. For. Meteorol. 2014, 197, 76-90.

8. Masmoudi, C.C.; Masmoudi, M.; Abid-Karray, J.E.N.; Mechlia, N.E.T.B. Sap flow measurements in young olive trees (Olea europaea L.) cv. Chetoui under Tunisian conditions. Sci. Hortic-Amst. 2011, 129, 520-527. [CrossRef]

9. Tie, Q.; Hu, H.C.; Tian, F.Q.; Guan, H.D.; Lin, H. Environmental and physiological controls on sap flow in a subhumid mountainous catchment in North China. Agric. For. Meteorol. 2017, 240, 46-57. [CrossRef]

10. Zhang, Y.; Kang, S.; Ward, E.J.; Ding, R.; Zhang, X.; Zheng, R. Evapotranspiration components determined by sap flow and microlysimetry techniques of a vineyard in northwest China: Dynamics and influential factors. Agric. Water Manag. 2011, 98, 1207-1214. [CrossRef]

11. Zang, C.X.; Yang, J.; Yuan, J.; Liu, X. Transpiration characteristics of individual shrubs of Caragana intermedia in mu us sandy land of north-central china. Chin. J. Plant Ecol. 2009, 33, 719-727. (In Chinese)

12. Huang, L.; Zhang, Z.S.; Li, X.R. Sap flow of Artemisia ordosica and the influence of environmental factors in a revegetated desert area: Tengger Desert, China. Hydrol. Process. 2010, 24, 1249-1253.

13. Huang, L.; Zhang, Z. Effect of rainfall pulses on plant growth and transpiration of two xerophytic shrubs in a revegetated desert area: Tengger Desert, China. Catena 2016, 137, 269-276. [CrossRef]

14. Zhao, W.; Liu, B. The response of sap flow in shrubs to rainfall pulses in the desert region of China. Agric. For. Meteorol. 2010, 150, 1297-1306. [CrossRef]

15. Jian, S.; Wu, Z.; Hu, C.; Zhang, X. Sap flow in response to rainfall pulses for two shrub species in the semiarid Chinese Loess Plateau. J. Hydrol. Hydromech. 2016, 64, 121-132. [CrossRef]

16. Hoelscher, M.; Kern, M.A.; Wessolek, G.; Nehls, T. A new consistent sap flow baseline-correction approach for the stem heat balance method using nocturnal water vapour pressure deficits and its application in the measurements of urban climbing plant transpiration. Agric. For. Meteorol. 2018, 248, 169-176. [CrossRef]

17. Chabot, R.; Bouarfa, S.; Zimmer, D.; Chaumont, C.; Moreau, S. Evaluation of the sap flow determined with a heat balance method to measure the transpiration of a sugarcane canopy. Agric. Water Manag. 2005, 75, 10-24. [CrossRef]

18. Yue, G.; Zhao, H.; Zhang, T.; Zhao, X.; Li, N.; Drake, S. Evaluation of water use of Caragana microphylla with the stem heat-balance method in Horqin Sandy Land, Inner Mongolia, China. Agric. For. Meteorol. 2008, 148, 1668-1678. [CrossRef]

19. Zha, T.S.; Qian, D.; Jia, X.; Bai, Y.J.; Tian, Y.; Bourque, C.P.A.; Ma, J.Y.; Feng, W.; Wu, B.; Peltola, H. Soil moisture control of sap-flow response to biophysical factors in a desert-shrub species, Artemisia ordosica. Biogeosciences 2017, 14, 4533-4544. [CrossRef]

20. Fu, W.; Huang, M.; Gallichand, J.; Shao, M. Optimization of plant coverage in relation to water balance in the Loess Plateau of China. Geoderma 2012, 173, 134-144. [CrossRef]

21. Wei, X.; Huang, M.; Shao, M.; Li, L.; Zhang, X.; Horton, R. Shrubs increase soil resources heterogeneity along semiarid grass slopes in the Loess Plateau. J. Arid Environ. 2013, 88, 175-183. [CrossRef]

22. Xu, M.; Zhang, J.; Liu, G.B.; Norikazu, Y. Soil properties in natural grassland, Caragana korshinskii planted shrubland, and Robinia pseudoacacia planted forest in gullies on the hilly Loess Plateau, China. Catena 2014, 119, 116-124. 
23. Duan, L.; Huang, M.; Zhang, L. Differences in hydrological responses for different vegetation types on a steep slope on the Loess Plateau, China. J. Hydrol. 2016, 537, 356-366. [CrossRef]

24. Liu, J.; Li, S.; Ouyang, Z.; Tam, C.; Chen, X. Ecological and socioeconomic effects of China's policies for ecosystem services. Proc. Natl. Acad. Sci. USA 2008, 105, 9477-9482. [CrossRef] [PubMed]

25. Yang, L.; Wei, W.; Chen, L.; Mo, B. Response of deep soil moisture to land use and afforestation in the semi-arid Loess Plateau, China. J. Hydrol. 2012, 475, 111-122. [CrossRef]

26. Sun, G.; Zhou, G.; Zhang, Z.; Wei, X.; Mcnulty, S.G.; Vose, J.M. Potential water yield reduction due to forestation across China. J. Hydrol. 2006, 328, 548-558. [CrossRef]

27. Mo, B.R.; Wang, Z.T.; Cai, G.J.; Yang, L.; Dang, H.Z.; Wang, D.F.; Xue, R. Soil water environment in different soil layers and influence factors of mature forest of Caragana korshinskii in semiarid loess area. Arid Land Geogr. 2014, 37, 1207-1215. (In Chinese)

28. Valancogne, C.; Nasr, Z. A heat balance method for measuring the sap flow in s mall trees. Agronomie 1989, 24, 383-385.

29. Yang, X.L.; Wei, X.R.; Shao, M.A. Stem biomass estimation models for dominant shrubs on the northern Loess Plateau of China. Chin. J. Appl. Ecol. 2016, 27, 3164-3172. (In Chinese)

30. Campbell, G.S.; Norman, J.M. Introduction to Environmental Biophysics; Springer: New York, NY, USA, 1998.

31. Du, S.; Wang, Y.L.; Kume, T.; Zhang, J.G.; Otsuki, K.; Yamanaka, N.; Liu, G.B. Sapflow characteristics and climatic responses in three forest species in the semiarid Loess Plateau region of China. Agric. For. Meteorol. 2011, 151, 1-10. [CrossRef]

32. Chen, D.; Wang, Y.; Liu, S.; Wei, X.; Wang, X. Response of relative sap flow to meteorological factors under different soil moisture conditions in rainfed jujube (Ziziphus jujuba Mill.) plantations in semiarid Northwest China. Agric. Water Manag. 2014, 136, 23-33. [CrossRef]

33. Allen, R.G.; Pereira, L.S.; Raes, D.; Smith, M. Crop Evapotranspiration: Guidelines for Computing Crop Water Requirements-FAO Irrigation and Drainage Paper 56; FAO: Rome, Italy, 1998; p. 300.

34. Cai, G.; Vanderborght, J.; Langensiepen, M.; Schnepf, A.; Hüging, H.; Vereecken, H. Root growth, water uptake, and sap flow of winter wheat in response to different soil water conditions. Hydrol. Earth Syst. Sci. 2018, 22, 2449-2470. [CrossRef]

35. Kigalu, J.M. Effects of planting density on the productivity and water use of tea (Camellia sinensis L.) clones: I. Measurement of water use in young tea using sap flow meters with a stem heat balance method. Agric. Water Manag. 2007, 90, 224-232. [CrossRef]

36. Arneth, A.; Kelliher, F.M.; Bauer, G.; Hollinger, D.Y.; Byers, J.N.; Hunt, J.E.; Mcseveny, T.M.; Ziegler, W.; Vygodskaya, N.N.; Milukova, I.; et al. Environmental regulation of xylem sap flow and total conductance of Larix gmelinii trees in eastern Siberia. Tree Physiol. 1996, 16, 247-255. [CrossRef] [PubMed]

37. Grady, O.A.P.; Worledge, D.; Battaglia, M. Constraints on transpiration of Eucalyptus globulus in southern Tasmania, Australia. Agric. For. Meteorol. 2008, 148, 453-465.

38. Zeppel, M.; Macinnis-Ng, C.M.O.; Ford, C.R.; Eamus, D. The response of sap flow to pulses of rain in a temperate Australian woodland. Plant Soil 2008, 305, 121-130. [CrossRef]

39. Pataki, D.E.; Oren, R.; Smith, W.K. Sap flux of co-occurring species in a western subalpine forest during seasonal soil drought. Ecology 2000, 81, 2557-2566. [CrossRef]

40. Oren, R.; Pataki, D.E. Transpiration in response to variation in microclimate and soil moisture in southeastern deciduous forests. Oecologia 2001, 127, 549-559. [CrossRef] [PubMed]

41. Ma, C.; Luo, Y.; Shao, M.; Li, X.; Sun, L.; Jia, X. Environmental controls on sap flow in black locust forest in Loess Plateau, China. Sci. Rep. 2017, 7, 13160. [CrossRef]

42. Horna, V.; Schuldt, B.; Brix, S.; Leuschner, C. Environment and tree size controlling stem sap flux in a perhumid tropical forest of Central Sulawesi, Indonesia. Ann. For. Sci. 2011, 68, 1027-1038. [CrossRef]

43. Ford, C.R.; Goranson, C.E.; Mitchell, R.J.; Will, R.E.; Teskey, R.O. Modeling canopy transpiration using time series analysis: A case study illustrating the effect of soil moisture deficit on Pinus taeda. Agric. For. Meteorol. 2005, 130, 163-175. [CrossRef]

44. Aguilos, M.; Stahl, C.E.M.; Burban, B.; Herault, B.; Courtois, E.; Coste, S.; Wagner, F.; Ziegler, C.; Takagi, K.; Bonal, D. Interannual and seasonal variations in ecosystem transpiration and water use efficiency in a tropical rainforest. Forests 2019, 10, 14. [CrossRef] 
45. Schulze, E.; Kelliher, F.M.; Korner, C.; Lloyd, J.; Leuning, R. Relationships among maximum stomatal conductance, ecosystem surface conductance, carbon assimilation rate, and plant nitrogen nutrition: A global ecology scaling exercise. Annu. Rev. Ecol. Syst. 1994, 25, 629-662. [CrossRef]

46. Chang, X.; Zhao, W.; He, Z. Radial pattern of sap flow and response to microclimate and soil moisture in Qinghai spruce (Picea crassifolia) in the upper Heihe River Basin of arid northwestern China. Agric. For. Meteorol. 2014, 187, 14-21. [CrossRef]

47. Nagler, P.L.; Glenn, E.P.; Thompson, T.L. Comparison of transpiration rates among saltcedar, cottonwood and willow trees by sap flow and canopy temperature methods. Agric. For. Meteorol. 2003, 116, 73-89. [CrossRef]

48. Xia, G.; Kang, S.; Li, F.; Zhang, J.; Zhou, Q. Diurnal and seasonal variations of sap flow of Caragana korshinskii in the arid desert region of north-west China. Hydrol. Process. 2007, 22, 1197-1205. [CrossRef]

49. Cermák, J.; Kucera, J.; Bauerle, W.L.; Phillips, N.; Hinckley, T.M. Tree water storage and its diurnal dynamics related to sap flow and changes in stem volume in old-growth Douglas-fir trees. Tree Physiol. 2007, 27, 181-198. [CrossRef]

50. Hatton, T.J.; Moore, S.J.; Reece, P.H. Estimating stand transpiration in a Eucalyptus populnea woodland with the heat pulse method: Measurement errors and sampling strategies. Tree Physiol. 1995, 15, 219-227. [CrossRef]

51. Burgess, S.S.O.; Dawson, T.E. Using branch and basal trunk sap flow measurements to estimate whole-plant water capacitance: A caution. Plan Soil 2008, 305, 5-13. [CrossRef]

52. Huang, L.; Zhang, Z.; Li, X. The extrapolation of the leaf area-based transpiration of two xerophytic shrubs in a revegetated desert area in the Tengger Desert, China. Hydrol. Res. 2015, 46, 389-399. [CrossRef]

53. Zhang, J.G.; Guan, J.; Shi, W.; Yamanaka, N.; Du, S. Interannual variation in stand transpiration estimated by sap flow measurement in a semi-arid black locust plantation, Loess Plateau, China. Ecohydrology 2015, 8, 137-147. [CrossRef]

54. Mcjannet, D.; Fitch, P.; Disher, M.; Wallace, J. Measurements of transpiration in four tropical rainforest types of north Queensland, Australia. Hydrol. Process. 2010, 21, 3549-3564. [CrossRef]

55. Zimmermann, R.; Schulze, E.D.; Wirth, C.; Schulze, E.E.; Mcdonald, K.C.; Vygodskaya, N.N.; Ziegler, W. Canopy transpiration in a chronosequence of Central Siberian pine forests. Glob. Chang. Biol. 2010, 6, $25-37$. [CrossRef]

(C) 2019 by the authors. Licensee MDPI, Basel, Switzerland. This article is an open access article distributed under the terms and conditions of the Creative Commons Attribution (CC BY) license (http://creativecommons.org/licenses/by/4.0/). 